\title{
2-Methoxyestradiol-induced Cell Death in Osteosarcoma Cells is Preceded by Cell Cycle Arrest
}

\author{
Avudaiappan Maran ${ }^{1},{ }^{*}$, Kristen L. Shogren ${ }^{1}$, Michaela Benedikt ${ }^{1}$, Gobinda Sarkar ${ }^{1}$, Russell \\ T. Turner ${ }^{2}$, and Michael J. Yaszemski ${ }^{1}$ \\ 1 Department of Orthopedics, Mayo Clinic, Rochester, Minnesota 55905 \\ 2 Department of Nutrition and Exercise Sciences, Oregon State University, Corvallis, Oregon 97330
}

\section{Abstract}

2-Methoxyestradiol (2-ME), a naturally occurring mammalian metabolite of $17 \beta$-Estradiol $\left(\mathrm{E}_{2}\right)$, induces cell death in osteosarcoma cells. To further understand the molecular mechanisms of action, we have investigated cell cycle progression in 2-ME-treated human osteosarcoma (MG63, SaOS-2 and LM8) cells. At $5 \mu \mathrm{M}, 2$-ME induced growth arrest by inducing a block in cell cycle; 2-MEtreatment resulted in 2-fold increases in G1 phase cells and a decrease in S phase cells in MG63 and SaOS-2 osteosarcoma cell lines, compared to the appropriate vehicle controls. 2-ME-treatment induced a 3-fold increase in the G2 phase in LM8 osteosarcoma cells. The results demonstrated steroid specificity, as the tumorigenic metabolite, 16 $\alpha$-hydroxyestradiol (16-OHE), did not have any effect on cell cycle progression in osteosarcoma cells. The cell cycle arrest coincided with an increase in expression of the cell cycle markers p21, p27 and p53 proteins in 2-ME-treated osteosarcoma cells. Also, MG63 cells, transiently transfected with cDNA for a "loss of function mutant" RNA-dependent protein kinase (PKR) protein, were resistant to 2-ME-induced cell cycle arrest. These results suggest that 2-ME works in concert with factors regulating cell cycle progression, and cell cycle arrest precedes cell death in 2-ME-treated osteosarcoma cells.

\section{Keywords}

estrogen metabolite; MG63 cells; cell cycle arrest; PKR

\section{Introduction}

$17 \beta$-Estradiol (E2) is metabolized by alternative hydroxylation pathways resulting in the formation of 2-, 4- and 16 $\alpha$-hydroxylated derivatives [Zhu and Conney, 1998a]. 16 $\alpha$-Hydroxyl derivatives are estrogen agonists in cultured osteoblasts and in ovariectomized rats [Lotinun et al., 2001; Robinson et al., 1997]. In contrast, 2-hydroxylated metabolites are neither estrogen agonists nor antagonists on bone cells in cell culture or in whole animals [Lotinun et al., 2001; Robinson et al., 1997]. 2-Hydroxyestradiol (2-OHE) undergoes further metabolism prior to clearance. 2-OHE is O-methylated at peripheral sites to form 2-methoxyestradiol (2-ME), which is present in human blood and urine [Fotsis et al., 1994; Gelbke and Knuppen, 1976]. The 4-and 16- $\alpha$-hydroxylation pathways are tumor promoting, whereas the 2-hydroxylation pathway has been shown to be tumor inhibitory [Zhu and Conney, 1998a]. 2-ME is highly cytotoxic to a wide range of tumor cells, but is harmless to most normal cells including normal osteoblasts [Maran et al., 2002; Schumacher et al., 1999]. However, 2-ME inhibits endothelial

*Address Correspondence to: Avudaiappan Maran, Ph.D., Department of Orthopedics, Mayo Clinic, 200 First Avenue SW, Medical Sciences Building 3-69, Rochester, MN 55905, Phone: 507-284-8783; Fax: 507-284-5075; maran@mayo.edu. 
cell proliferation and angiogenesis [Fotsis et al., 1994; Yue et al., 1997; Zhu and Conney, 1998a], as well as vascular invasion of growth plate cartilage [Sibonga et al., 2002].

2-ME is a potential therapeutic agent for treatment of bone cancer [Maran et al., 2002; Shogren, 2007]. The molecular mechanism of action of 2-ME on osteosarcoma cells is not well understood, but appears to involve RNA-dependent protein kinase (PKR) signaling [Shogren, 2007]. To further understand the actions of 2-ME and determine whether 2-ME exerts similar effects on various osteosarcoma cell lines, we have investigated the effects of 2-ME on cell cycle progression in low metastatic (MG63 and SaOS-2) and high metastatic (LM8) osteosarcoma cell lines.

\section{Materials and Methods}

\section{Cell Culture}

Human osteosarcoma cells (MG63, SaOS-2 and LM8) were grown in DMEM/F12 medium containing 10\% charcoal-stripped fetal bovine serum (FBS), penicillin, streptomycin and geneticin $(300 \mu \mathrm{g} / \mathrm{mL})$ and maintained at $37^{\circ} \mathrm{C}$ under $5 \% \mathrm{CO}_{2}$.

\section{Metabolite Treatment and Cell Proliferation}

The human osteosarcoma cells were plated at $5 \times 10^{4}$ cells per well into 24 well plates containing $1 \mathrm{ml} /$ well medium. After allowing the cells to attach overnight, the media in the wells were replaced with fresh $1 \mathrm{ml}$ medium. The metabolites were added into each well containing the test compounds or carrier and maintained for $72 \mathrm{hrs}$. At the end of treatment, the cell growth was measured by MTS-based cell viability assay systems as per the manufacturer's protocol (Promega, Madison, WI).

17 $\beta$-Estradiol ( $\left.\mathrm{E}_{2}\right), 2$-methoxyestradiol (2-ME) and 16 $\alpha$-hydroxyestradiol (16-OHE) were purchased from Sigma Chemical Co. (St. Louis, MO). Stock solutions of the metabolites at their respective concentrations were made in $95 \%$ ethanol.

\section{Analysis of Cell Cycle Distribution}

The human (MG 63, SaOS-2 and LM8) osteosarcoma cells $\left(1 \times 10^{6}\right.$ cells) were plated in T-75 flasks and maintained for $24 \mathrm{hrs}$. The next day media were changed, and the cells were treated with vehicle (ethanol) or $10 \mu \mathrm{M} \mathrm{E}_{2}, 2-\mathrm{ME}$ and 16-OHE. After $24 \mathrm{hrs}$ of treatment, the cells were trypsinized, spun and washed with PBS. Each sample was then fixed on ice by adding $300 \mu \mathrm{l}$ of cold $95 \%$ ethanol drop-wise for 5 minutes. After allowing the cells to fix on ice for $1 \mathrm{hr}$, they were then washed with PBS three times and resuspended in RNase A solution and stained with propidium iodide $(50 \mu \mathrm{g} / \mathrm{ml})$. The samples were then analyzed, and the percentage of cells in each phase of the cell cycle was determined using a FACS Scan unit (Becton Dickinson, San Jose, CA). The relative proportions of cells in the G1, S, and G2/M cell cycle phases were estimated by compartment analysis of DNA fluorescence using cell cycle analysis software from the manufacturer.

\section{Transient Transfection}

MG63 cells plated in T-75 flasks were transfected at $60 \%$ confluence with $5 \mu \mathrm{g}$ of pcDNA3PKR-K296R or empty vector pcDNAneo using the transfection agent lipofectamine, as described in the manufacturer's protocol (Invitrogen, Carlsbad, California). Twenty-four hours post transfection, the cells were treated with vehicle and 2-ME. Cells were processed for cell cycle studies after $24 \mathrm{hrs}$ of treatment, as described above. 


\section{Preparation of Cytoplasmic Extract and Protein Analysis}

Cytoplasmic extracts were prepared as described [Kennedy et al., 2005]. Briefly, cells harvested after 2-ME treatment were lysed by suspending in Nonidet P-40 lysis buffer containing $0.5 \%$ Nonidet P-40; $90 \mathrm{mM} \mathrm{KCl} ; 1 \mathrm{mM}$ magnesium acetate; $2 \mathrm{mM} 2$ mercaptoethanol; $10 \mathrm{mg} / \mathrm{mL}$ leupeptin; and $10 \mathrm{mM}$ HEPES (pH 7.6). After centrifugation at $10,000 \times \mathrm{g}$ for $10 \mathrm{~min}$, the resultant supernatant containing cytoplasmic extract (60 $\mu \mathrm{g}$ protein) was analyzed by Western blot hybridization using anti-p21, anit-p53 (Cell Signaling, Danvers, MA), anti-p27(Santa Cruz Biotechnology, Santa Cruz, CA) and anti-actin (Sigma) antibodies.

\section{Results}

\section{2-ME Induces a Cell Cycle Block in MG63 Osteosarcoma Cells}

To assess the effect of various estrogenic compounds on cell cycle progression, we have performed flow cytometry analyses in Veh, 2-ME, $\mathrm{E}_{2}$ and 16-OHE-treated osteosarcoma cells. The results show that 2-ME treatment contributed to a 2-fold increase and a 2.3-fold decrease in percentage of cells in G1 phase and S phase, respectively (Fig. 1B) compared to the vehicle control (Fig. 1A). The tumorigenic metabolite 16 $\alpha-$ OHE did not induce similar effects in G1 and S phase cells (Fig. 1D). The parent estrogen, $17 \beta$-estradiol had minimal effects on the cells in G1phase, but decreased the cells in S phase by 2-fold.

\section{2-ME Affects the Growth of SaOS-2 and LM8 Osteosarcoma Cells}

The MTS-based cell viability assay carried out at $72 \mathrm{hrs}$ after 2-ME treatment shows a dosedependent effect on cell survival in several osteosarocoma cell lines (Fig. 2). In the case of SaOS-2 cells, the cell survival was reduced to $83 \%, 77 \%, 38 \%, 34 \%, 33 \%$ and $33 \%$, respectively, in the presence of 1,2,5,10,20 and 50 $\mu \mathrm{M}$ 2-ME compared to vehicle control (Fig. 2A). Similarly, the results show that LM8 cell survival was reduced to $36 \%, 32 \%, 26 \%$, $21 \%, 19 \%$ and $17 \%$, respectively, in the presence of 1, 2, 5, 10, 20 and $50 \mu \mathrm{M}$ 2-ME (Fig. 2B) compared to the vehicle control.

To determine whether the 2-ME-mediated cell death is preceded by cell cycle block in SaOS-2 and LM8 osteosarocoma cells, we have analyzed the effect of 2-ME on cell cycle progression by flow cytometry analysis in SaOS-2 and LM8 osteosarcoma cells. 2-ME treatment increased the cells in G1 phase by 2-fold in SaOS-2 compared to the vehicle control (Fig. 3A \& 3B). In the case of LM8 cells, 2-ME treatment did not increase G1 phase, but resulted in a 2.3-fold increase in $\mathrm{G} 2$ phase cells compared to the vehicle (Fig. 3C \& 3D).

\section{2-ME Alters the Expression of Proteins Involved in Cell Cycle Regulation}

In order to determine whether 2-ME-induced cell cycle block is accompanied by changes in proteins involved in cell cycle regulation, we have studied the expression of p21, p27 and p53 proteins in various osteosarcoma cell lines. Fig. 4A shows that 2-ME treatment leads to an increase in $\mathrm{p} 21$ protein levels in MG63, SaOS-2 and LM8 cells compared to the vehicle control. 2-ME treatment also induces the expression of p27 protein in MG63 and SaoS2 osteosarcoma cells, but does not affect the expression in LM8 cells (Fig. 4B). p53 level increases in 2-MEtreated MG63 cells whereas it does not change with 2-ME treatment in SaOS2 and LM8 cells (Fig. 4C). Our results show that the control actin protein does not change with the 2-ME treatment in these cells (Fig. 4D).

\section{A Dominant Negative Mutant, PKR, Inhibits 2-ME-dependent Cell Cycle Arrest}

Our earlier studies showed that RNA-dependent protein kinase, PKR, is involved in 2-MEmediated cell death [Shogren, 2007]. PKR protein is regulated in a cell cycle-dependent manner. To understand the role of PKR protein in 2-ME-mediated growth arrest in 
osteosarcoma cells, we have investigated MG63 cells that transiently express the dominant negative PKR mutant protein, which has been shown to block endogenous PKR protein functions. 2-ME is ineffective in inducing growth arrest and G1/S block in the presence of dominant negative mutant PKR protein expression (Fig. 5B) compared to the vehicle control (Fig. 5A). However, in cells transfected with control vector, 2-ME induced the G1/S block (Fig. 5D).

\section{Discussion}

Estrogen is metabolized into compounds that activate pathways which, depending upon the metabolite, can either block or induce cell growth. 2-ME, which is a product of 2-hydroxylation pathway, exerts anti-tumor effects in vivo and in vitro [Maran et al., 2002; Mukhopadhyay and Roth, 1997; Pribluda et al., 2000; Schumacher et al., 1999; Seegers et al., 1997; Zhu and Conney, 1998b]. We have previously shown that 2-ME induces cell death in osteosarcoma cells, but does not affect normal osteoblasts [Maran et al., 2002]. We have demonstrated that the mechanism of 2-ME-mediated cell killing in osteosarcoma cells involves apoptosis [Maran et al., 2002; Shogren, 2007]. In this study, we show that 2-ME blocks the progression of osteosarcoma cells at G1/S or G2/M boundary during cell cycle and demonstrate that growth arrest precedes cell death.

The anti-tumor and anti-growth mechanisms of 2-ME involve multiple, cell-specific pathways including disruption of microtubles, induction of oncogenes, cytokines and growth arrest. 2ME-dependent tumor cell death and other anti-tumor effects (e.g., inhibition of angiogenesis) are associated with growth arrest due to the inability of the cells to progress through the cell cycle. 2-ME treatment results in G1 arrests in breast cancer cells [Lottering et al., 1992] and chondrosarcoma cells [Fong et al., 2007]. In contrast, G2/M arrest has been demonstrated in 2-ME-treated endothelial, breast cancer, prostate cancer and hepatoma cells [Kumar et al., 2001; Lin et al., 2000; Qadan et al., 2001; Reiser et al., 1998]. The results show that in the presence of 2-ME, cell cycle progression is blocked at G1/S boundary in MG63 and SaOS-2 osteosarcoma cells, but at G2/M boundry in LM8 osteosarocoma cells. Thus, 2-ME induces G2/M block in highly metastatic tumor cells, but not in low metastatic cells. This finding suggests that distinct tumor inducing pathways are involved in vivo in tumor progression by low metastatic and high metastatic cells. Thus, multiple mechanisms could be involved in 2ME-induced growth arrests in osteosarcoma cells, which could eventually converge to a tumor inhibitory pathway. Further investigation is necessary to delineate the molecular signals associated with 2-ME-induced growth arrest at different stages of the cell cycle in osteosarcoma cells with high metastatic potential.

Cell cycle progression in eukaryotic cells involves numerous regulatory proteins that control progression of cells through each phase of the cycle. One of these factors is a cyclin-dependent kinase (CDK) inhibitor, p21 (also called WAF-1or CIP1), which was initially thought to function as a negative regulator of cell cycle progression [el-Deiry et al., 1993; Harper et al., 1993; Noda et al., 1994; Xiong et al., 1993]. The cell cycle inhibitory effects of p21 may be attributed to its ability to bind CDKs as proliferating cell nuclear antigen (PCNA), resulting in the inhibition of cell cycle progression. p21 plays an essential role in growth arrest after DNA damage [Harper et al., 1993; Noda et al., 1994; Xiong et al., 1993]. The present studies show that the p21 is induced with 2-ME treatment. Previous reports show that overexpression of p21 leads to G1 and G2 arrests [Niculescu et al., 1998; Ogryzko et al., 1997]. p21 is induced by both p53-dependent and -independent mechanisms [Gartel and Tyner, 1999]. Although it was originally known as a p53-targeted gene, p21 has been implicated as a downstream effector of various tumor suppressors, growth factors and cytokines including breast cancer gene BRCA-1, Wnt-1, interferon and transforming growth factor- $\beta$ [Datto et al., 1995; Englert et al., 1997; Jiang et al., 1994; Katayama T et al., 2007; Somasundaram et al., 1997]. p21 participates in 
both pro-apoptotic and anti-apoptotic functions in response to various anti-tumor agents depending upon the cellular context [Gartel and Tyner, 2002; Liu et al., 2003].

2-ME treatment is accompanied by increases in $\mathrm{p} 21$ protein levels in colorectal cancer, hepatocelluar carcinoma, melanoma, prostate cancer cells, non-small cell lung cancer [Carothers et al., 2002; Ghosh et al., 2003; Huober et al., 2000; Kumar et al., 2001; Schumacher et al., 2006], and, in this study, multiple osteosarcoma cell lines. The present studies show that p21 is induced in 2-ME-treated osteosarcoma cells during G1 and G2 growth arrest and suggest p21 contributes to the cell killing. However, not all of the effects of 2-ME can be attributed to increased p21 levels. In nasopharyngeal carcinoma cells, the anti-tumor effects of 2-ME are not accompanied by changes in p21 expression [Zhou et al., 2004]. In addition, 2-ME-mediated cell cycle arrest in smooth muscle cells was accompanied by a decrease in p21 levels [Barchiesi et al., 2006].

The present studies show that another kinase inhibitor, p27 protein, is increased with 2-ME treatment in osteosarcoma cells. p27 negatively regulates G1/S transition [Hershko and Shapira, 2006]. Low or absent p 27 expression is frequently observed in many human cancers, including breast, prostate, gastric, lung and colorectal cancer [Catzavelos et al., 1997; Esposito et al., 1997; Loda et al., 1997; Mori et al., 1997; Tsihlias et al., 1999; Tsihlias et al., 1998]. Furthermore, downregulation of p27 is strongly associated with aggressive tumor and poor prognosis. Our results provide additional support that $\mathrm{p} 27$ upregulation is associated with antitumor effects of 2-ME. Additionally, 2-ME increased p27 expression in low metastatic cells (MG63 and SaOS2), but not in high metastatic cells (LM8) suggesting the involvement of different anti-tumor mechanisms in low and high metastatic cells.

p53 protein is a transcription factor and a tumor suppressor that has several anti-cancer mechanisms, including activation of DNA repair proteins, induction of cell cycle block and induction of apoptosis. 2-ME treatment increases expression of functional and wildtype p53 in cancer cells resulting in apoptosis. The requirement of p53 in non-2-ME-mediated and 2ME-mediated induction of apoptosis was documented [Aylon and Oren, 2007; Chen et al., 1996; Mukhopadhyay and Roth, 1997; Mukhopadhyay and Roth, 1998; Vousden, 2006]. On the other hand, it has been shown that growth arrest and apoptosis may occur in 2-ME-treated cells independent of p53 [Pribluda et al., 2000; Schumacher et al., 1999]. The present studies show that 2-ME treatment leads to an increase in p53 protein levels in MG63 cells. In contrast, p53 expression is not affected in other osteosarcoma cell lines (SaOS2, LM8). Thus, 2-MEdependent cell death of osteosarcoma cells depends upon cell type and further confirms that 2-ME actions involves p53-dependent and p53-independent mechanisms.

PKR is a potent negative regulator of cell growth in eukaryotic cells [Barber, 2005; Clemens, 2003; Williams, 1999]. In addition, ectopic expression of catalytically inactive mutants of PKR in NIH3T3 cells led to their transformation and subsequent formation of tumors when these cells were injected into nude mice [Barber et al., 1995; Koromilas et al., 1992; Meurs et al., 1993]. This appears to be due to the interference with the activity of endogenous wild type PKR by the overexpressed mutant protein [Barber et al., 1995; Koromilas et al., 1992; Meurs et al., 1993]. PKR regulates $\mathrm{p} 53$-dependent cell cycle arrest and G1/S arrest and p21-dependent transcriptional inductions were impaired in PKR-/- cells [Cuddihy et al., 1999]. Also, PKR is essential for 2-ME-induced cell death in human osteosarcoma cells [Shogren, 2007]. Current results add additional support to this conclusion and demonstrates that PKR is essential for 2ME-mediated cell cycle regulation. Specifically, inhibition of endogenous PKR protein in the presence of dominant negative mutant PKR protein reverses 2-ME-dependent cell cycle arrest. Also, $\mathrm{E}_{2}$ and 16-OHE do not trigger G1/S arrest. Thus, steroids that are chemically similar to 2-ME that do not induce PKR expression [Shogren, 2007], do not have any effect on cell cycle progression. These findings further link the upregulation of PKR to the cell cycle arrest at G1/ 
$\mathrm{S}$ phase boundary in the presence of 2-ME treatment. p21 regulation appears to take place upstream of PKR induction as inhibition of PKR does not have any effect on p21 induction in 2-ME-treated cells (Shogren and Maran, unpublished). Detailed investigation could delineate the various molecular steps involved in 2-ME-dependent cell cycle arrest.

In conclusion, the present studies show that the cell cycle arrest precedes cell death in 2-MEtreated osteosarcoma cells. 2-ME regulates p21, p27, p53 and PKR factors that control cell cycle progression and influence osteosarcoma cells, leading to the blockade of cell cycle progression and cell death. Further investigation of the factors that contribute to the growth arrest will lead to a better understanding of the anti-tumor mechanisms and improved therapeutic application of this promising drug, 2-ME.

\section{Acknowledgments}

These studies were supported by NIH Grants CA10287801, AR047974, AA011140 and the Mayo Clinic. We thank Ms. Angela Kennedy for technical assistance and Dr. Michael Mathews (University of Medicine and Dentistry of New Jersey, Newark, NJ) for the pcDNA3-PKR-K296R plasmid.

Grant Information: NIH Grants CA10287801, AR047974 and the Mayo Clinic

\section{References}

Aylon Y, Oren M. Living with p53, dying of p53. [comment]. Cell 2007;130:597-600. [PubMed: 17719538]

Barber GN. The dsRNA-dependent protein kinase, PKR and cell death. Cell Death Differ 2005;12:563570. [PubMed: 15846372]

Barber GN, Jagus R, Meurs EF, Hovanessian AG, Katze MG. Molecular mechanisms responsible for malignant transformation by regulatory and catalytic domain variants of the interferon-induced enzyme RNA-dependent protein kinase. J Biol Chem 1995;270:17423-17428. [PubMed: 7615547]

Barchiesi F, Jackson EK, Fingerle J, Gillespie DG, Odermatt B, Dubey RK. 2-Methoxyestradiol, an estradiol metabolite, inhibits neointima formation and smooth muscle cell growth via double blockade of the cell cycle.[see comment]. Circulation Research 2006;99:266-274. [PubMed: 16794187]

Carothers AM, Hughes SA, Ortega D, Bertagnolli MM. 2-Methoxyestradiol induces p53-associated apoptosis of colorectal cancer cells. Cancer Letters 2002;187:77-86. [PubMed: 12359354]

Catzavelos C, Bhattacharya N, Ung YC, Wilson JA, Roncari L, Sandhu C, Shaw P, Yeger H, MoravaProtzner I, Kapusta L, Franssen E, Pritchard KI, Slingerland JM. Decreased levels of the cell-cycle inhibitor p27Kip1 protein: prognostic implications in primary breast cancer.[see comment]. Nature Medicine 1997;3:227-230.

Chen X, Ko LJ, Jayaraman L, Prives C. p53 levels, functional domains, and DNA damage determine the extent of the apoptotic response of tumor cells. Genes \& Development 1996;10:2438-2451. [PubMed: 8843196]

Clemens MJ. Interferons and apoptosis. J Interferon Cytokine Res 2003;23:277-292. [PubMed: 12859854]

Cuddihy AR, Li S, Tam NW, Wong AH, Taya Y, Abraham N, Bell JC, Koromilas AE. Double-strandedRNA-activated protein kinase PKR enhances transcriptional activation by tumor suppressor p53. Molecular \& Cellular Biology 1999;19:2475-2484. [PubMed: 10082513]

Datto MB, Li Y, Panus JF, Howe DJ, Xiong Y, Wang XF. Transforming growth factor beta induces the cyclin-dependent kinase inhibitor p21 through a p53-independent mechanism. Proceedings of the National Academy of Sciences of the United States of America 1995;92:5545-5549. [PubMed: 7777546]

el-Deiry WS, Tokino T, Velculescu VE, Levy DB, Parsons R, Trent JM, Lin D, Mercer WE, Kinzler KW, Vogelstein B. WAF1, a potential mediator of p53 tumor suppression. Cell 1993;75:817-825. [PubMed: 8242752]

Englert C, Maheswaran S, Garvin AJ, Kreidberg J, Haber DA. Induction of p21 by the Wilms' tumor suppressor gene WT1. Cancer Res 1997;57:1429-1434. [PubMed: 9108440] 
Esposito V, Baldi A, De Luca A, Groger AM, Loda M, Giordano GG, Caputi M, Baldi F, Pagano M, Giordano A. Prognostic role of the cyclin-dependent kinase inhibitor p27 in non-small cell lung cancer. Cancer Res 1997;57:3381-3385. [PubMed: 9270000]

Fong YC, Yang WH, Hsu SF, Hsu HC, Tseng KF, Hsu CJ, Lee CY, Scully SP. 2-methoxyestradiol induces apoptosis and cell cycle arrest in human chondrosarcoma cells. Journal of Orthopaedic Research 2007;25:1106-1114. [PubMed: 17415781]

Fotsis T, Zhang Y, Pepper MS, Adlercreutz H, Montesano R, Nawroth PP, Schweigerer L. The endogenous oestrogen metabolite 2-methoxyoestradiol inhibits angiogenesis and suppresses tumour growth. Nature 1994;368:237-239. [PubMed: 7511798]

Gartel AL, Tyner AL. Transcriptional regulation of the p21((WAF1/CIP1)) gene. Experimental Cell Research 1999;246:280-289. [PubMed: 9925742]

Gartel AL, Tyner AL. The role of the cyclin-dependent kinase inhibitor p21 in apoptosis. Molecular Cancer Therapeutics 2002;1:639-649. [PubMed: 12479224]

Gelbke HP, Knuppen R. The excretion of five different 2-hydroxyoestrogen monomethyl ethers in human pregnancy urine. J Steroid Biochem 1976;7:457-463. [PubMed: 966757]

Ghosh R, Ott AM, Seetharam D, Slaga TJ, Kumar AP. Cell cycle block and apoptosis induction in a human melanoma cell line following treatment with 2-methoxyoestradiol: therapeutic implications? Melanoma Research 2003;13:119-127. [PubMed: 12690294]

Harper JW, Adami GR, Wei N, Keyomarsi K, Elledge SJ. The p21 Cdk-interacting protein Cip1 is a potent inhibitor of G1 cyclin-dependent kinases. Cell 1993;75:805-816. [PubMed: 8242751]

Hershko DD, Shapira M. Prognostic role of p27Kip1 deregulation in colorectal cancer. Cancer 2006;107:668-675. [PubMed: 16826582]

Huober JB, Nakamura S, Meyn R, Roth JA, Mukhopadhyay T. Oral administration of an estrogen metabolite-induced potentiation of radiation antitumor effects in presence of wild-type p53 in nonsmall-cell lung cancer. International Journal of Radiation Oncology, Biology, Physics 2000;48:11271137.

Jiang H, Lin J, Su ZZ, Collart FR, Huberman E, Fisher PB. Induction of differentiation in human promyelocytic HL-60 leukemia cells activates p21, WAF1/CIP1, expression in the absence of p53. Oncogene 1994;9:3397-3406. [PubMed: 7936668]

Katayama T, Nakanishi K, Nishihara H, Kamiyama N, Nakagawa T, Kamiyama T, Iseki KTS, ST. Type I interferon prolongs cell cycle progression via p21WAF1/CIP1 induction in human colon cancer cells. Int J Oncol 2007;31:613-620. [PubMed: 17671689]

Kennedy AM, Shogren KL, Zhang M, Turner RT, Spelsberg TC, Maran A. 17beta-estradiol-dependent activation of signal transducer and activator of transcription-1 in human fetal osteoblasts is dependent on Src kinase activity. Endocrinology 2005;146:201-207. [PubMed: 15471961]

Koromilas AE, Roy S, Barber GN, Katze MG, Sonenberg N. Malignant transformation by a mutant of the IFN-inducible dsRNA-dependent protein kinase. Science 1992;257:1685-1689. [PubMed: 1382315]

Kumar AP, Garcia GE, Slaga TJ. 2-methoxyestradiol blocks cell-cycle progression at G(2)/M phase and inhibits growth of human prostate cancer cells. Molecular Carcinogenesis 2001;31:111-124. [PubMed: 11479920]

Lin HL, Liu TY, Chau GY, Lui WY, Chi CW. Comparison of 2-methoxyestradiol-induced, docetaxelinduced, and paclitaxel-induced apoptosis in hepatoma cells and its correlation with reactive oxygen species. Cancer 2000;89:983-994. [PubMed: 10964328]

Liu S, Bishop WR, Liu M. Differential effects of cell cycle regulatory protein p21(WAF1/Cip1) on apoptosis and sensitivity to cancer chemotherapy. Drug Resistance Updates 2003;6:183-195. [PubMed: 12962684]

Loda M, Cukor B, Tam SW, Lavin P, Fiorentino M, Draetta GF, Jessup JM, Pagano M. Increased proteasome-dependent degradation of the cyclin-dependent kinase inhibitor p27 in aggressive colorectal carcinomas.[see comment]. Nature Medicine 1997;3:231-234.

Lotinun S, Westerlind KC, Turner RT. Tissue-selective effects of continuous release of 2-hydroxyestrone and 16alpha-hydroxyestrone on bone, uterus and mammary gland in ovariectomized growing rats. Journal of Endocrinology 2001;170:165-174. [PubMed: 11431149] 
Lottering ML, Haag M, Seegers JC. Effects of 17 beta-estradiol metabolites on cell cycle events in MCF-7 cells. Cancer Res 1992;52:5926-5932. [PubMed: 1327520]

Maran A, Zhang M, Kennedy AM, Sibonga JD, Rickard DJ, Spelsberg TC, Turner RT. 2Methoxyestradiol Induces Interferon Gene Expression and Apoptosis in Osteosarcoma Cells. BONE 2002;30:393-398. [PubMed: 11856647]

Meurs EF, Galabru J, Barber GN, Katze MG, Hovanessian AG. Tumor suppressor function of the interferon-induced double-stranded RNA-activated protein kinase. Proc Natl Acad Sci USA 1993;90:232-236. [PubMed: 7678339]

Mori M, Mimori K, Shiraishi T, Tanaka S, Ueo H, Sugimachi K, Akiyoshi T. p27 expression and gastric carcinoma. Nature Medicine 1997;3:593.

Mukhopadhyay T, Roth JA. Induction of apoptosis in human lung cancer cells after wild-type p53 activation by methoxyestradiol. Oncogene 1997;14:379-384. [PubMed: 9018125]

Mukhopadhyay T, Roth JA. Superinduction of wild-type p53 protein after 2-methoxyestradiol treatment of Ad5p53-transduced cells induces tumor cell apoptosis. Oncogene 1998;17:241-246. [PubMed: 9674709]

Niculescu AB 3rd, Chen X, Smeets M, Hengst L, Prives C, Reed SI. Effects of p21(Cip1/Waf1) at both the G1/S and the G2/M cell cycle transitions: $p R b$ is a critical determinant in blocking DNA replication and in preventing endoreduplication.[erratum appears in Mol Cell Biol 1998 Mar;18(3): 1763]. Molecular \& Cellular Biology 1998;18:629-643. [PubMed: 9418909]

Noda A, Ning Y, Venable SF, Pereira-Smith OM, Smith JR. Cloning of senescent cell-derived inhibitors of DNA synthesis using an expression screen. Experimental Cell Research 1994;211:90-98. [PubMed: 8125163]

Ogryzko VV, Wong P, Howard BH. WAF1 retards S-phase progression primarily by inhibition of cyclindependent kinases. Molecular \& Cellular Biology 1997;17:4877-4882. [PubMed: 9234744]

Pribluda VS, Gubish ER Jr, Lavallee TM, Treston A, Swartz GM, Green SJ. 2-Methoxyestradiol: an endogenous antiangiogenic and antiproliferative drug candidate. Cancer Metastasis Rev 2000;19:173-179. [PubMed: 11191057]

Qadan LR, Perez-Stable CM, Anderson C, D'Ippolito G, Herron A, Howard GA, Roos BA. 2Methoxyestradiol induces G2/M arrest and apoptosis in prostate cancer. Biochemical \& Biophysical Research Communications 2001;285:1259-1266. [PubMed: 11478793]

Reiser F, Way D, Bernas M, Witte M, Witte C. Inhibition of normal and experimental angiotumor endothelial cell proliferation and cell cycle progression by 2-methoxyestradiol. Proceedings of the Society for Experimental Biology \& Medicine 1998;219:211-216. [PubMed: 9824543]

Robinson JA, Harris SA, Riggs BL, Spelsberg TC, Turner RT, Kidder LS, Zhang M, Westerlind KC. Estrogen regulation of human osteoblastic cell proliferation and differentiation. Endocrinology 1997;138:2919-2927. [PubMed: 9202236]

Schumacher G, Kataoka M, Roth JA, Mukhopadhyay T. Potent antitumor activity of 2-methoxyestradiol in human pancreatic cancer cell lines. Clin Cancer Res 1999;5:493-499. [PubMed: 10100698]

Schumacher G, Scheunert S, Rueggeberg A, Bachem MG, Nussler AK, Spinelli A, Mukhopadhyay T, Pratschke J, Neuhaus P. A very low toxic agent induces apoptosis and reduces growth of human hepatocellular carcinoma cells. Journal of Gastroenterology \& Hepatology 2006;21:1207-1212. [PubMed: 16824077]

Seegers JC, Lottering ML, Grobler CJ, van Papendorp DH, Habbersett RC, Shou Y, Lehnert BE. The mammalian metabolite, 2-methoxyestradiol, affects P53 levels and apoptosis induction in transformed cells but not in normal cells. J Steroid Biochem Mol Biol 1997;62:253-267. [PubMed: 9408079]

Shogren K. Double-stranded RNA Dependent Protein Kinase Is Involved in 2-MethoxyestradiolMediated Cell Death in Osteosarcoma Cells. J Bone Miner Res 2007:22.

Sibonga JD, Sommer U, Turner RT. Evidence that 2-methoxyestradiol suppresses proliferation and accelerates apoptosis in normal rat growth plate chondrocytes. Journal of Cancer Research \& Clinical Oncology 2002;128:477-483. [PubMed: 12242511]

Somasundaram K, Zhang H, Zeng YX, Houvras Y, Peng Y, Wu GS, Licht JD, Weber BL, El-Deiry WS. Arrest of the cell cycle by the tumour-suppressor BRCA1 requires the CDK-inhibitor p21WAF1/ CiP1. Nature 1997;389:187-190. [PubMed: 9296497] 
Tsihlias J, Kapusta L, Slingerland J. The prognostic significance of altered cyclin-dependent kinase inhibitors in human cancer. Annual Review of Medicine 1999;50:401-423.

Tsihlias J, Kapusta LR, DeBoer G, Morava-Protzner I, Zbieranowski I, Bhattacharya N, Catzavelos GC, Klotz LH, Slingerland JM. Loss of cyclin-dependent kinase inhibitor p27Kip1 is a novel prognostic factor in localized human prostate adenocarcinoma. Cancer Res 1998;58:542-548. [PubMed: 9458103]

Vousden KH. Outcomes of p53 activation--spoilt for choice. Journal of Cell Science 2006;119:50155020. [PubMed: 17158908]

Williams BR. PKR; a sentinel kinase for cellular stress. Oncogene 1999;18:6112-6120. [PubMed: 10557102]

Xiong Y, Hannon GJ, Zhang H, Casso D, Kobayashi R, Beach D. p21 is a universal inhibitor of cyclin kinases.[see comment]. Nature 1993;366:701-704. [PubMed: 8259214]

Yue TL, Wang X, Louden CS, Gupta S, Pillarisetti K, Gu JL, Hart TK, Lysko PG, Feuerstein GZ. 2Methoxyestradiol, an endogenous estrogen metabolite, induces apoptosis in endothelial cells and inhibits angiogenesis: possible role for stress-activated protein kinase signaling pathway and Fas expression. Mol Pharmacol 1997;51:951-962. [PubMed: 9187261]

Zhou NN, Zhu XF, Zhou JM, Li MZ, Zhang XS, Huang P, Jiang WQ. 2-Methoxyestradiol induces cell cycle arrest and apoptosis of nasopharyngeal carcinoma cells. Acta Pharmacologica Sinica 2004;25:1515-1520. [PubMed: 15525476]

Zhu BT, Conney AH. Functional role of estrogen metabolism in target cells: review and perspectives. Carcinogenesis 1998a;19:1-27. [PubMed: 9472688]

Zhu BT, Conney AH. Is 2-methoxyestradiol an endogenous estrogen metabolite that inhibits mammary carcinogenesis? Cancer Res 1998b;58:2269-2277. [PubMed: 9622057] 
A. Veh

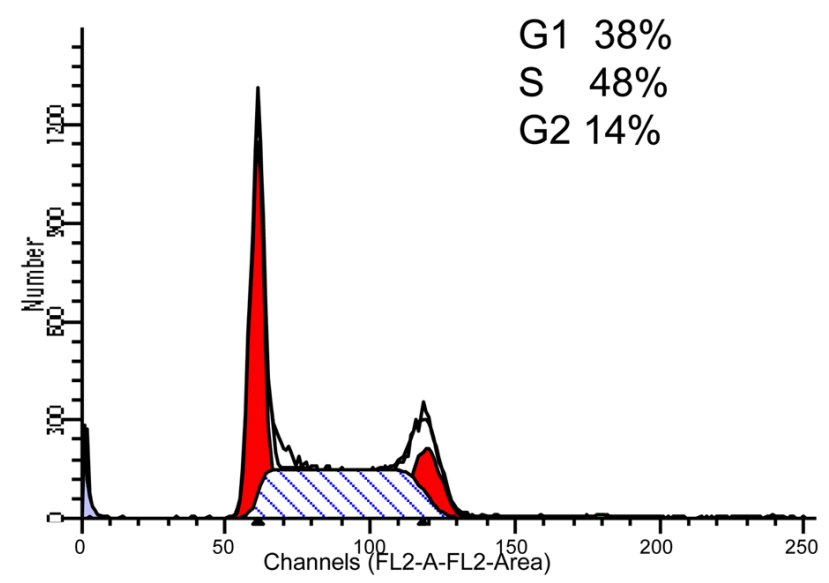

C. $\mathrm{E}_{2}$

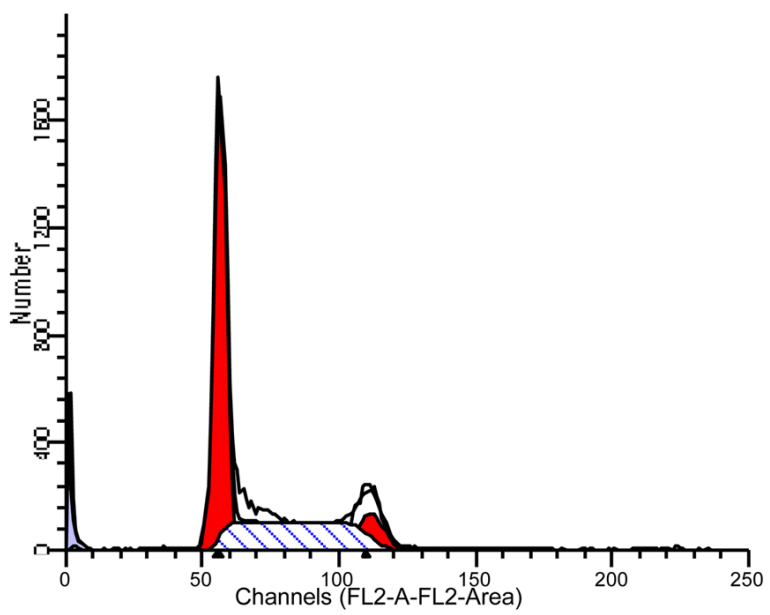

B. 2-ME

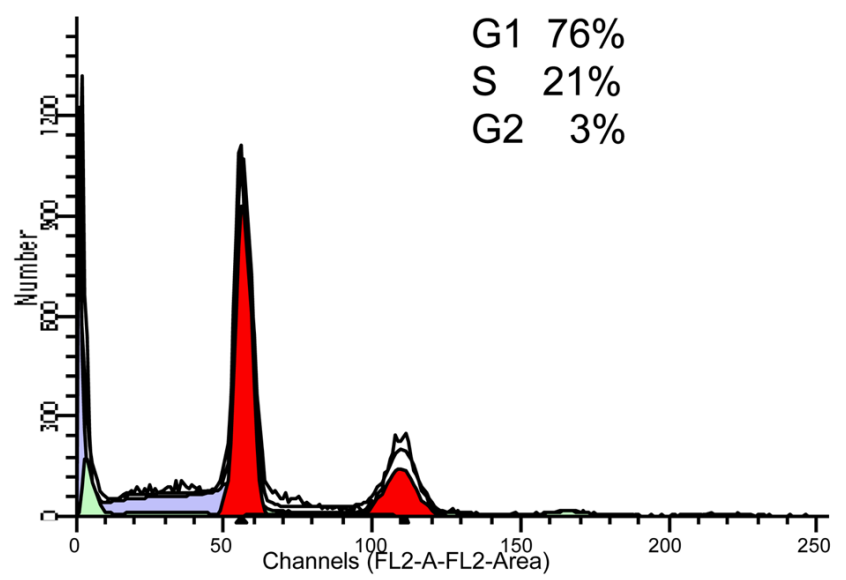

D. $16 \alpha-\mathrm{OHE}$

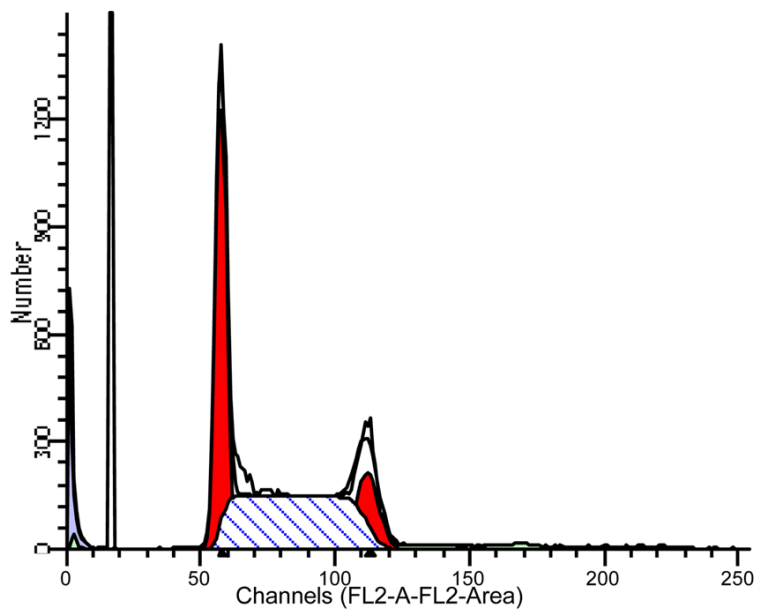

Fig. 1.

Ligand specific cell cycle arrest in osteosarcoma cells. MG63 cells were treated with Veh, vehicle (A), $10 \mu \mathrm{M}$ of 2-ME (B), E2, 17 $\beta$-estradiol (C) and 16 $\alpha$-OHE, 16 $\alpha$-hydroxyestradiol (D) for $24 \mathrm{hr}$ and analyzed using a FACS Scan unit. 
A. SaOS-2

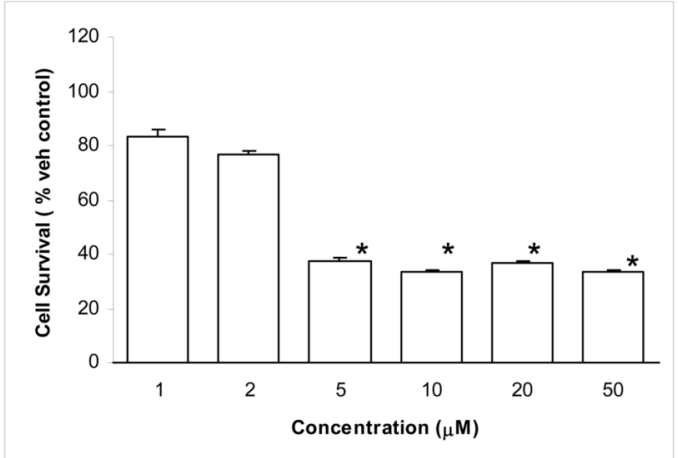

B. LM 8

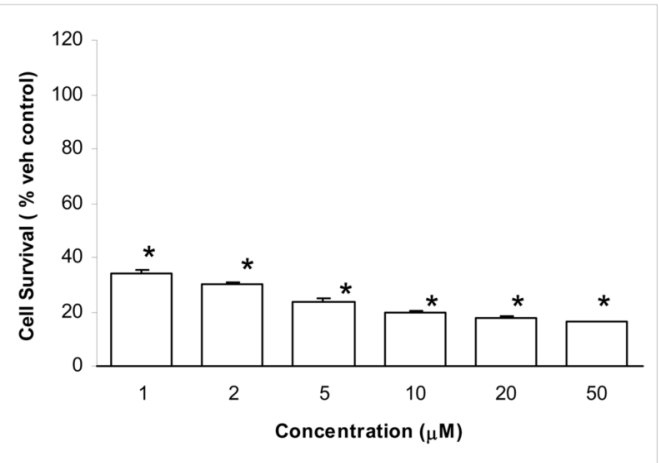

Fig. 2.

2-ME induces cell death in SaoS-2 (A) and LM8 (B) osteosarcoma cell lines. Osteosarcoma cells were treated with Veh or $5 \mu \mathrm{M}$ of 2-ME for $72 \mathrm{hrs}$. The cells were harvested and the proliferation was determined by MTS assay. Values are the mean $\pm \mathrm{SE}$ ( $\mathrm{N}=3$ replicate cultures). The absence of error bar denotes a line thickness greater than the error. $* \mathrm{P} \leq 0.05$ versus Veh. 


\section{SaOS-2}

A. Veh

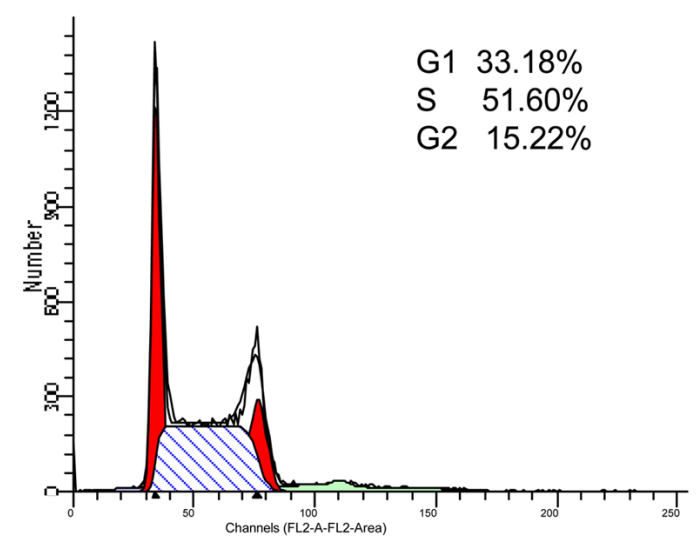

LM8

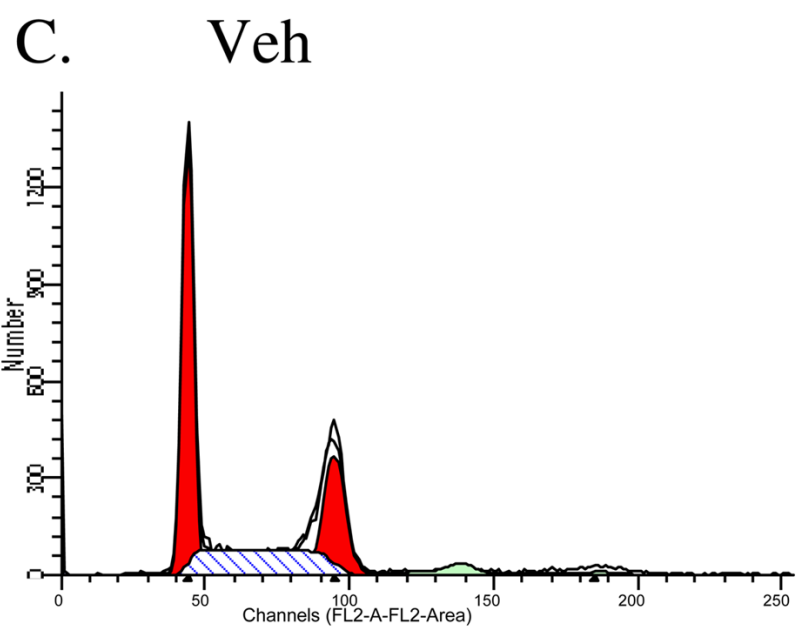

B. 2-ME

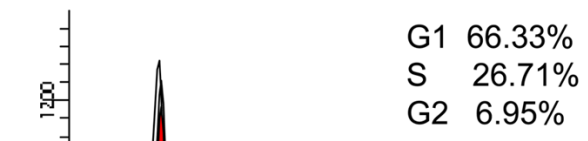

D. 2-ME

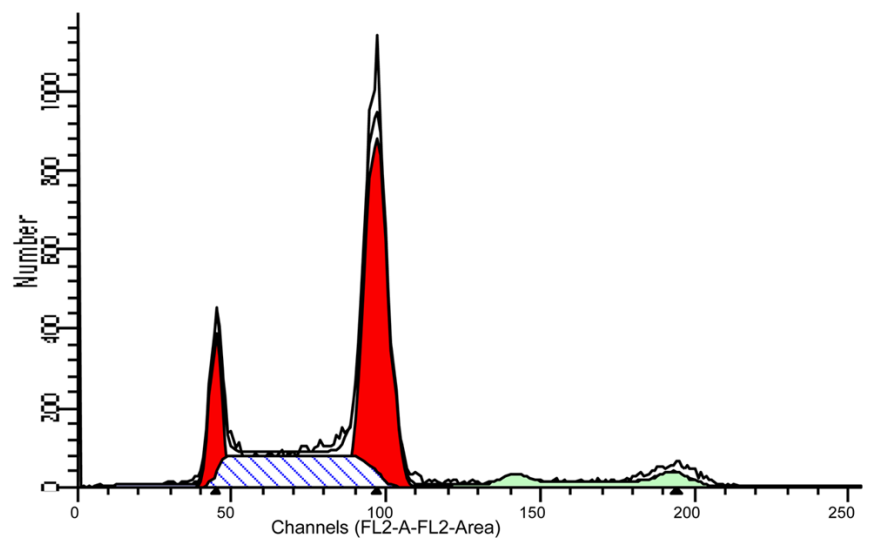

Fig. 3.

Flow cytometry in osteosarcoma cells. SaOS-2 and LM8 cells were treated with Veh (A \& C) or $10 \mu \mathrm{M}$ 2-ME (B \& D) for 24hrs and analyzed using a FACS Scan unit. 


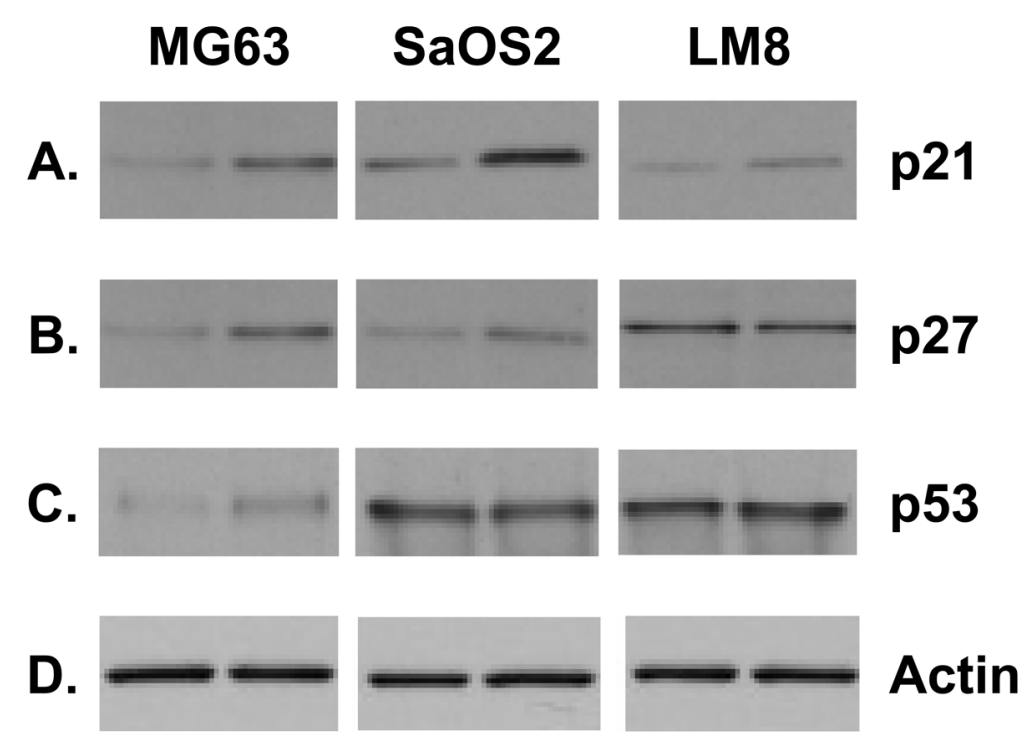

Fig. 4.

2-ME treatment increases p21 protein levels. Cytoplasmic extracts prepared from osteosarcoma cells treated with Veh and $10 \mu \mathrm{M}$ 2-ME for 24 hrs were analyzed by Western blot hybridization using anti-p21 (A), anti-p53 (C) (Cell Signaling Technology) anti-p27 (B) (Santa Cruz Biotechnology) and anti-actin (D) (Sigma) antibodies. 


\section{pcDNA3-PKR-K296R transfected}
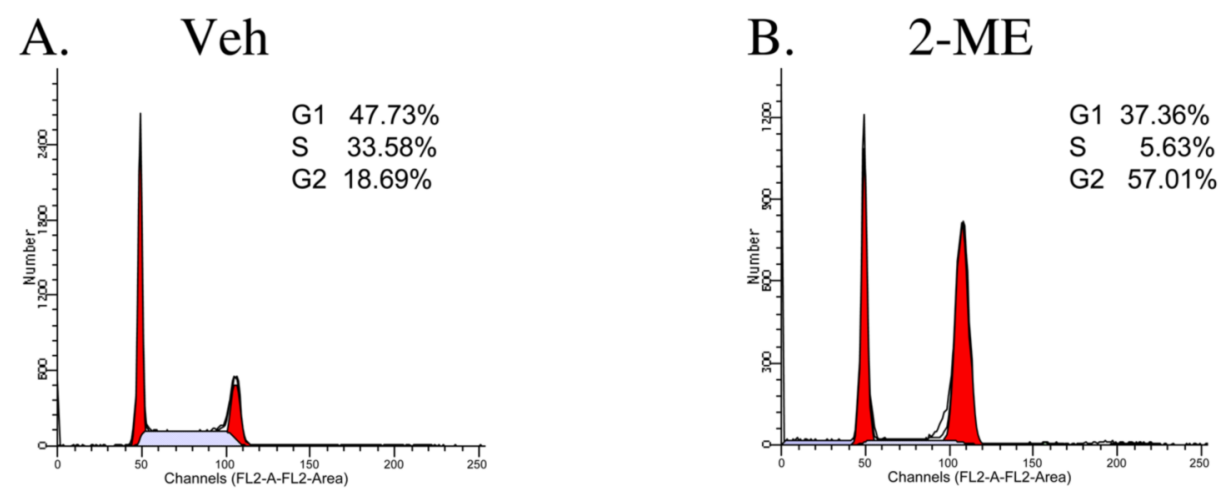

\section{pcDNA-neo transfected}
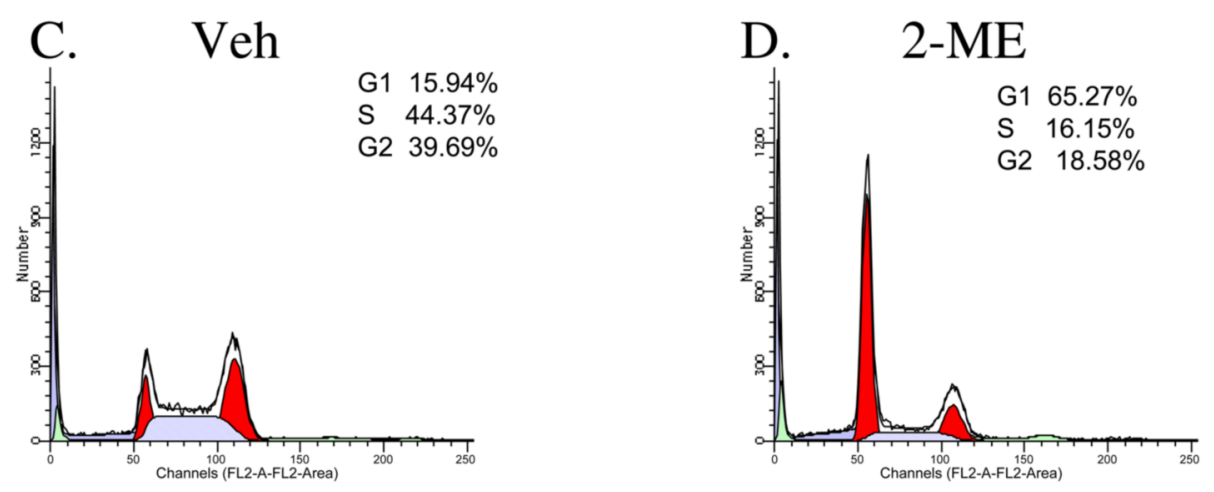

Fig. 5.

Dominant negative PKR blocks 2-ME-mediated cell cycle arrest. MG63 cells were transfected with the plasmid pCDNA3-PKR-K296R (A \& B) or empty vector pcDNA neo (C \&D) and treated with Veh or $10 \mu \mathrm{M} 2-\mathrm{ME}$ for $24 \mathrm{hr}$. The cells were harvested and analyzed by flow cytometry. 